\title{
USE, MANAGEMENT AND SPATIAL ANALYSIS OF WOOD RESOUR- CES IN THE IBERIAN OPPIDUM OF PUENTE TABLAS (JAÉN, SPAIN)
}

\author{
MARÍA OLIVA RODRÍGUEZ-ARIZA ${ }^{(1)}$
}

\begin{abstract}
:
The oppidum of Puente Tablas, under excavation since 1985 by a team from the University of Jaen, has revealed complex planning with different functional areas: Gate, Sanctuary, Palace, and neighbourhood Houses. By systematic flotation sampling, we compiled a significant number of charcoal remains and performed a spatial analysis of charcoal results. Also, these results indicate the different uses of certain woody species, revealing the management of wood resources of this Iron Age settlement

Keywords: Charcoal analysis, Iberians, Iron Age, Southern Iberian Peninsula, Spatial analysis

Resumen:

Uso, gestión y análisis espacial de los recursos forestales en el Oppidum ibérico de Puente Tablas (Jaén, España) El oppidum de Puente Tablas, excavado desde 1985 por un equipo de la Universidad de Jaén, ha puesto al descubierto la existencia de áreas diferenciadas a nivel funcional y urbanístico: puerta, santuario, palacio y casas. La realización de un muestreo sistemático de flotación nos ha permitido la obtención de numerosas muestras antracológicas que nos permiten realizar un análisis espacial de los resultados obtenidos. Asimismo, la contrastación de los mismos nos permite empezar a ver los usos que se dieron a las distintas especies leñosas determinadas y comenzar a calibrar la gestión de los recursos forestales de esta población de la Edad del Hierro.
\end{abstract}

Palabras-clave: Antracología, Iberos, Edad del Hierro, Sur de la Península Ibérica, Análisis espacial.

Received: 20 September, 2016; Accepted: 6 March, 2017

\section{INTRODUCTION}

Charcoal analysis is normally used to identify the flora and the composition of local and regional plant communities of the past. The classical charcoal analyses in the Mediterranean region have focused on assembling a palaeo-environmental sequence and on establishing a methodology for the accurate ecological interpretation of anthropic charcoal remains (e.g. ChABAL 1992; FigueIRAL 1993; BADAL et al. 1994; VERNET 1997).

Slower progress has been made in studies on the use and management of woody resources by prehistoric, protohistoric, and ancient communities (RODRÍGUEZ-ARIZA 1989-90, FIGUEIRAL 1996; GARCÍA \& GRAU 2005; MARSTON 2009; RODRÍGUEZARIZA \& MONTES 2010; RUBIALES et al., 2011). This is partly because of the very characteristics of archaeological excavations, generally circumscribed within small areas or samples that do not reveal the different contexts within the overall settlement. However, there are also limitations of the charcoal itself, as it is often difficult to distinguish its origin between natural and human processes.

The present study focuses on one of the largest Iberian settlements excavated in the southern Iberian Peninsula, enabling us to evaluate the anthracological information from different zones with several levels, i.e. from the entire settlement to the distinction between zones and spaces within the excavated area. In addition, this settlement has been approached from different archaeological perspectives, such as the urbanism, archaeoastronomy, artefacts, chemical analyses of sediments and ceramics (see RUIZ et al. 2015; RUIZ et al. 2015; PARRAS et al. 2015; SÁNCHEZ et al. 2014), and environmental analyses (RODRÍGUEZ-ARIZA \& PRADAS 2015; MONTES, 2015). This set of information begins to reveal the uses of different woody species, making it possible to calibrate the management of certain forest resources of this Iron Age population.

\section{ECOLOGICAL AND ARCHAEOLOGICAL CONTEXTS}

The Iberian fortified settlement, or oppidum, of Puente Tablas ( $37^{\circ} 48^{\prime} 44^{\prime \prime}$ N, 344'58' 'E, $420 \mathrm{~m}$. asl) is located on the right bank of the Guadalbullón river, $5 \mathrm{~km}$ from the city of Jaén. Geographically, it is situated in the south of the Iberian Peninsula, in the eastern part of the Guadalquivir Valley, within what is called Campiñas de Jaén (Fig. 1). This area is made up of Neogene and Quaternary sedimentary rocks that formed from marine sediments deposited from the strait that up to $5 \mathrm{Ma}$ connected the ancient Mediterranean Sea with the Atlantic Ocean at the site currently occupied by the Guadalquivir basin. This gave rise to a depressed, hilly relief composed of marls, sandstones, and conglomerates, currently planted with broad extensions of olive orchards.

This region has been under intense human exploitation for several millennia, which has changed the landscape. The natural vegetation is relegated to the surrounding mountains, i.e. the Sierra Morena to the north and the Subbetic Systems to the south, as well as other isolated points. The 
potential vegetation is medium-sized oak woodlands, with a tree stratum composed almost entirely of Holm oak (Quercus ilex), though certain especially shady areas harbour Portuguese oak (Quercus faginea).

Biogeographically, the area belongs to the Mediterranean region and within the chorological typology to the Betic province. The dominant vegetation series is the oak woodland (Quercus rotundifolia: Paeonio coriaceae-Querceto rotundifoliae $S$.) in its thermophilic faction with mastic tree (Pistacia lentiscus) (RIVAS MARTíNEZ 1987; VALLE 2003). In this thermophilic faciation, the oak woodland is enriched in species with thermophilic preferences, such as mastic trees and wild olive (Olea europaea sylvestris). The site is located between the Thermomediterranean and Mesomediterranean bioclimatic belts and the Dry-Subhumid ombroclimate ( $\mathrm{P}$ 300-1000).

The Iberians were the most advanced culture of the Iberian Peninsula during the Iron Age. Beginning around the $6^{\text {th }}$ century B.C., the Iberian Culture developed and reached its zenith during the $5^{\text {th }}$ and $3^{\text {rd }}$ B.C.. Geographically, this culture extended throughout the south and eastern half of the Iberian Peninsula and the south-eastern portion of what is currently France, representing a clear Mediterranean culture (RUIZ \& MOLINOS 1998).

The oppidum of Puente Tablas is located on two hilltops with an artificial profile determined by the irregular line of a powerful fortification following the changing elevations and irregularities of the terrain. The settlement is completely walled except for the western side, where a rocky outcrop serves as a barrier (Fig. 1). The site is clearly well suited and strategic, overlooking the fertile farmland below and lying close to gypsum and red-ochre mines, as well as guarding the transport route of the Guadalbullón river, which flows into the Guadalquivir, crossing the Campiña area (Fig. 2).

Since 1985, different excavations have been made by the team from the University of Jaén, Spain (RUIZ \& MOLINOS 2008, 2015), documenting the occupation of the hilltop since the Late Bronze Age to the Islamic era, although the Iberian period $\left(6^{\text {th }}\right.$ to $3^{\text {rd }}$ centuries B.C.) marks its maximum splendour and development. Archaeologically, several phases of construction have been distinguished. Phases IV and $\mathrm{V}$ correspond to the Ancient Iberian period ( $6^{\text {th }}$ to the first half of the $5^{\text {th }}$ century B.C.) and Phases VI and VII to the Middle Iberian period (second half of the $5^{\text {th }}$ century to the mid- $4^{\text {th }}$ century B.C.). After a populational hiatus, the village became reinhabited at the end of the $3^{\text {rd }}$ century B.C., this constituting Phase VIII, belonging to the Late Iberian period.

The latest excavations have uncovered the remains of a palace (RUIZ et al. 2015) and a sanctuary close to the Eastern Gate of the oppidum (RUIZ et al. 2015). This constitutes an urban plan in which we can delineate several zones: city walls, gates, houses, a palace, and a sanctuary (Fig. 1). The Sanctuary and the Eastern Gate were built in the second half of the $5^{\text {th }}$ century B.C. under strict astronomical principles of a goddess cult. In the two equinox periods, the sunlight entering through the gate cast sunlight and shadows on the stone figure of the goddess, highlighting its features. This system persisted until the end of the $4^{\text {th }}$ century B.C. (RUIZ et al. 2015).

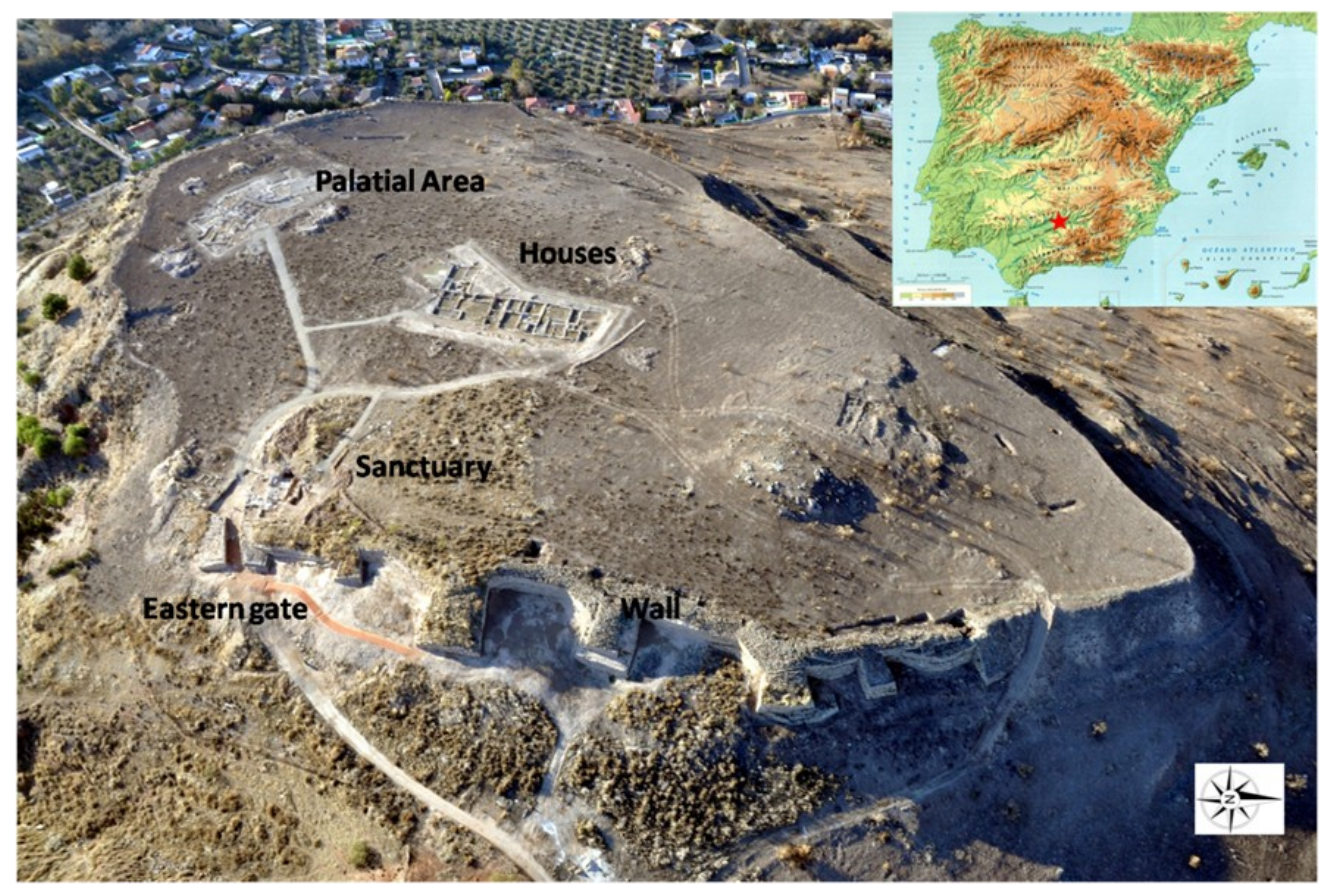

Fig. 1. Aerial view of Puente Tablas and its geographical situation, showing the excavated areas.

Fig. 1. Vista aérea de Puente Tablas con las zonas excavadas y situación geográfica. 


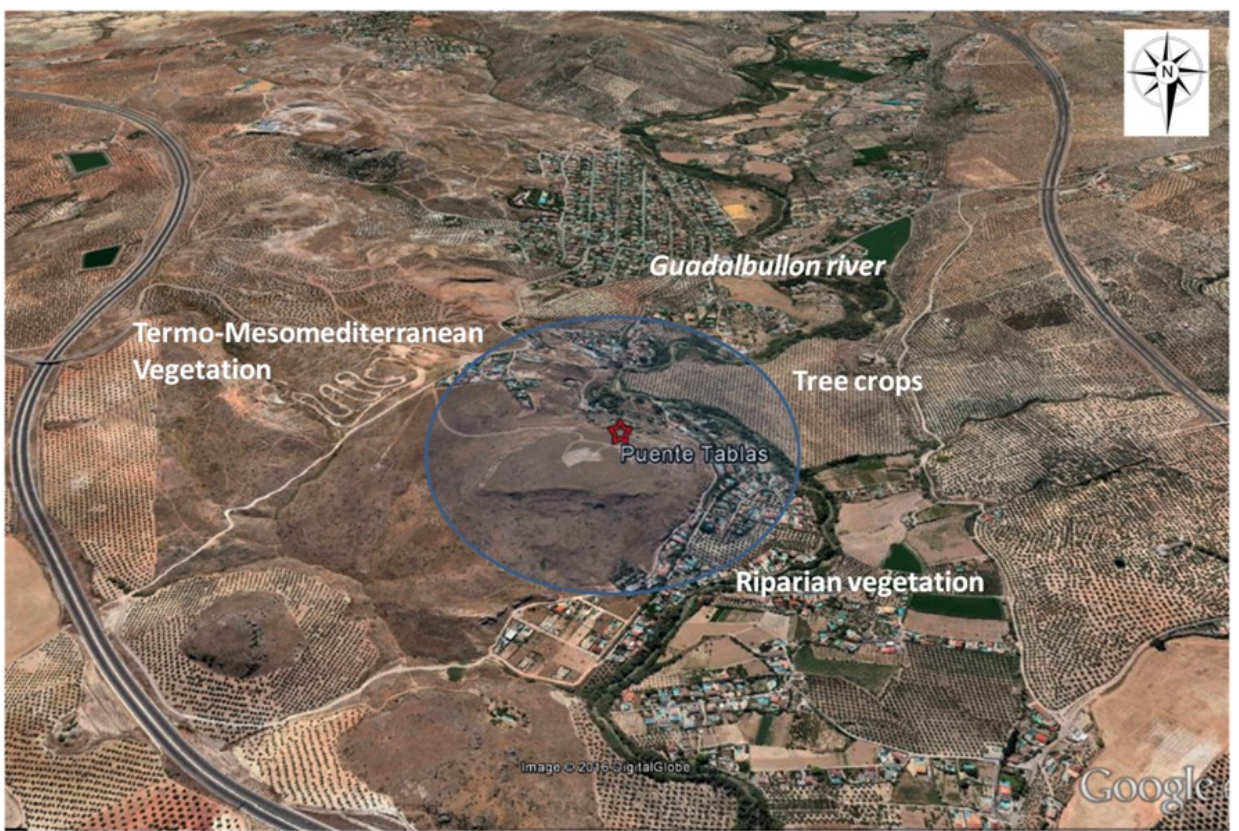

Fig. 2. Aerial view from the north (Google maps) of the Guadalbullón river valley, indicating the possible areas of plant provisioning.

Fig. 2. Vista aérea (a partir de google maps) del valle del río Guadalbullón desde el Norte, con la indicación de las posibles áreas de aprovisionamiento de la vegetación.

\section{MATERIALS AND METHODS}

In the latest excavations, a systematic sampling gathered sediment for flotation in order to recover charcoal and seeds. This sampling collected at least 40 litres of the stratigraphic unit excavated, although the volume was increased in the units that, after the initial test, showed archaeobotanical remains. The sediments were processed by manual flotation, using screens of 0.2-mm mesh size. Apart from the flotation, charcoal was recovered directly during the excavation, although findings were scarce. Therefore, there were not enough charcoal samples in the zones where sediments were not systematically collected for flotation, as in the case of the Houses, the Eastern Gate, and the City Wall.

For the palaeoecological evaluation of the charcoal analysis, the overall data compiled at the oppidum were used, whereas for the spatial study of the results, we considered only the data gathered in the Sanctuary and the Palace, comparing the two zones (semi-micro level) and the different settings or rooms defined in each of the two zones (micro level).

After verifying that there are no significant differences of vegetation at the diachronic level, it was decided to perform the micro study in the Sanctuary comparing a total of 15 structures. Most of them belong to the PTVI Phase (first half of the $4^{\text {th }}$ century B.C.), while four structures, which did not belong strictly to the Sanctuary (AE, S6, AF-Ext. and Cubeta) although to its service area they are of the PTV Phase (end of $5^{\text {th }}$ century B.C.). In the village, of the 22 structural complexes defined, only 5 presented a high enough number of charcoal samples to be able to compare them, two of them ( $\mathrm{r}$ and ext.) belong to the phase PTVII (second half of the $4^{\text {th }}$ century B.C.), while the other 3 (h, pyn) belong to the Last Iberian phase of the site (PTVIII - S.III BC).

In the laboratory, for the anthracological study, the charcoal had to be sectioned manually, seeking to provide three planes: transverse, longitudinaltangential, and longitudinal-radial. Each plane allowed the identification of elements of the internal structure of the wood, where the form, size, and disposition varied according to the species to which the charcoal belonged.The charcoal was identified by comparing several atlases of wood anatomy (SCHWEINGRUBER 1990; VERNET 2001; SCHWEINGRUBER et al. 2011, 2013) as well as with the collection of present-day charred woods available in the Palaeoenvironmental Laboratory of the University Research Institute for Iberian Archaeology of the University of Jaén.

Samples of charred Mediterranean wood can identified to the species level, although in certain cases only the genus can be determined, as in the case of Acer, Cistus, Crataegus, Juniperus, and Tamarix.

The charcoal was studied under a reflectedlight microscope and the scanning electron microscope (SEM). The light microscope, which has a set of interchangeable lenses from 100 to $500 \mathrm{x}$ and a micrometer to make biometric measurements, was used for the bulk of the taxonomic identification, while the electron microscope from the Centre of Scientific-Technical Instruments of the University of Jaén was used to photograph or identify the doubtful samples. 


\section{RESULTS}

The charcoal studied from Puente Tablas came from all the areas of the site, although most were from the latest excavations, where 13,131 litres of sediment were processed by manual flotation $(6,263$ from the Palace and 6,268 from the Sanctuary). The total of 3,148 carbon fragments with the following distribution were analysed: Sanctuary, 1,755: Palace, 1,210; Houses, 51; Eastern Gate, 112; City Wall, 20.

In the overall oppidum, a total of 28 taxa were identified, arriving in 10 cases the species: Arbutus unedo (strawberry tree), Juglans regia (walnut), Olea europaea (olive/wild olive), Pinus halepensis (Aleppo pine), Pistacia lentiscus (mastic tree), Prunus domestica (plum), Prunus dulcis (almond), Quercus faginea (Portuguese oak), Rosmarinus officinalis (rosemary), and Vitis vinifera (grapevine). Among these species, special attention was placed on the distinction between different Prunus species, distinguishable for the width of the radii of the growth rings (VERNET et al., 2001 and SCWEINGRUBER 1990), as plum has 1-6 cells, occasionally up to 10 , though most frequently 4 -6 ; meanwhile, almond usually has thicker rings, of 4 -8 cells, occasionally up to $10-12$. In two cases, the taxa represented two species: Quercus ilex/coccifera for Holmes oak and Kermes oak; and Pinus nigrasylvestris (black pine and Scots pine). Another 11 taxa represented different genera: Cistus sp. (rockrose), Crataegus sp. (hawthorn), Fraxinus sp. (ash), Juniperus sp. (juniper), Phillyrea sp. (phillyrea), Pinus sp. (pines), Pistacia sp. (pistaches), Populus sp. (poplars and cottonwood), Prunus sp. (prunoids), Salix sp. (willows) and Tamarix sp. (tamarisks). In two cases, two distinct genera are represented: Rhamnus/Phillyrea (buckthorn and phillyrea) and Salix/Populus (willows and poplars). The designation "deciduous Quercus" includes the fragments that had a porous ring. These fragments could belong to $Q$. faginea (Portuguese oak) or $Q$. pyrenaica (Pyrenean oak), both species being frequent in this region. In other cases, only a higher level was identified: the family Leguminosae (legumes), and the order Monocotyledoneae (monocotyledons).

In this list, we can clearly distinguish those that belong to the natural vegetation of the Mediterranean area and cultivated species (introduced). In turn, the natural vegetation can be divided into several groups: climatic vegetation, including another two groups; Mediterranean Thermophilic, composed of strawberry tree, rockrose, junipers, shrubby legumes, monocots, wild olive, phillyrea, Aleppo pine, pine, mastic tree, pistaches, Holmes oak/kermes oak, buckthorn/phillyrea, and rosemary; and the Meso-Supramediterranean, with black pine/Scots pine, Portuguese oak/Pyrenean oak, and riparian vegetation such as ash, poplar, and willow. The cultivated species include walnut, plum, almond, and grape.

To define the taxa that were most commonly used and that in all probability define the plant community of the surroundings, we performed a ubiquity analysis of these taxa in the 60 contexts or structural complexes defined in all the areas excavated of the oppidum (Fig. 3). The species that appeared in the greatest number of structures were ash, followed by Holm oak/kermes oak and the strawberry tree. In fourth and fifth place appeared the fruit trees (plum and almond), followed by willows/poplars and finally Aleppo pine. These same taxa proved most abundant in the overall oppidum (Fig. 4), except that the willows/poplars and Aleppo pine switched position. Therefore, overall, for their ubiquity as well as their representation, the predominant taxa were the same. Among these, three groups of vegetation used appear to have been: riverside ash, willows, and/or poplar, the climatic natural area with Holm oak/ kermes oak, strawberry tree and Aleppo pine, and the cultivated area with plum and almond.

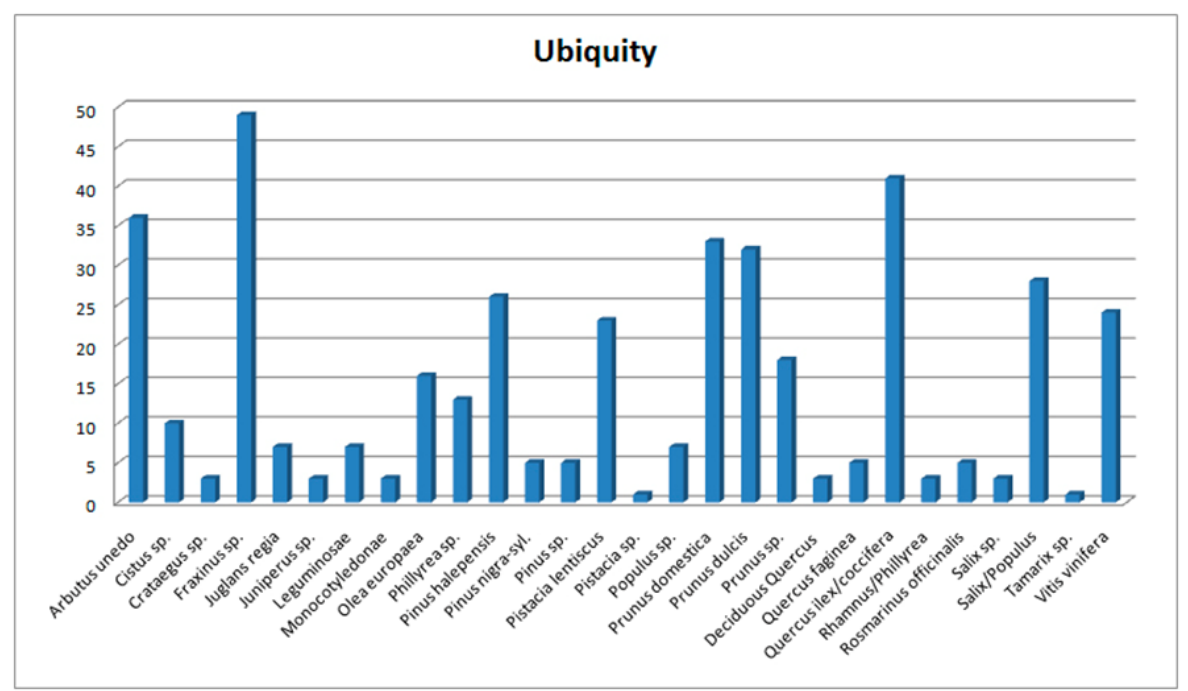

Fig. 3. Presence of the different taxa in the 60 structural complexes defined.

Fig. 3. Aparición de los distintos taxones en los 60 Complejos Estructurales definidos. 


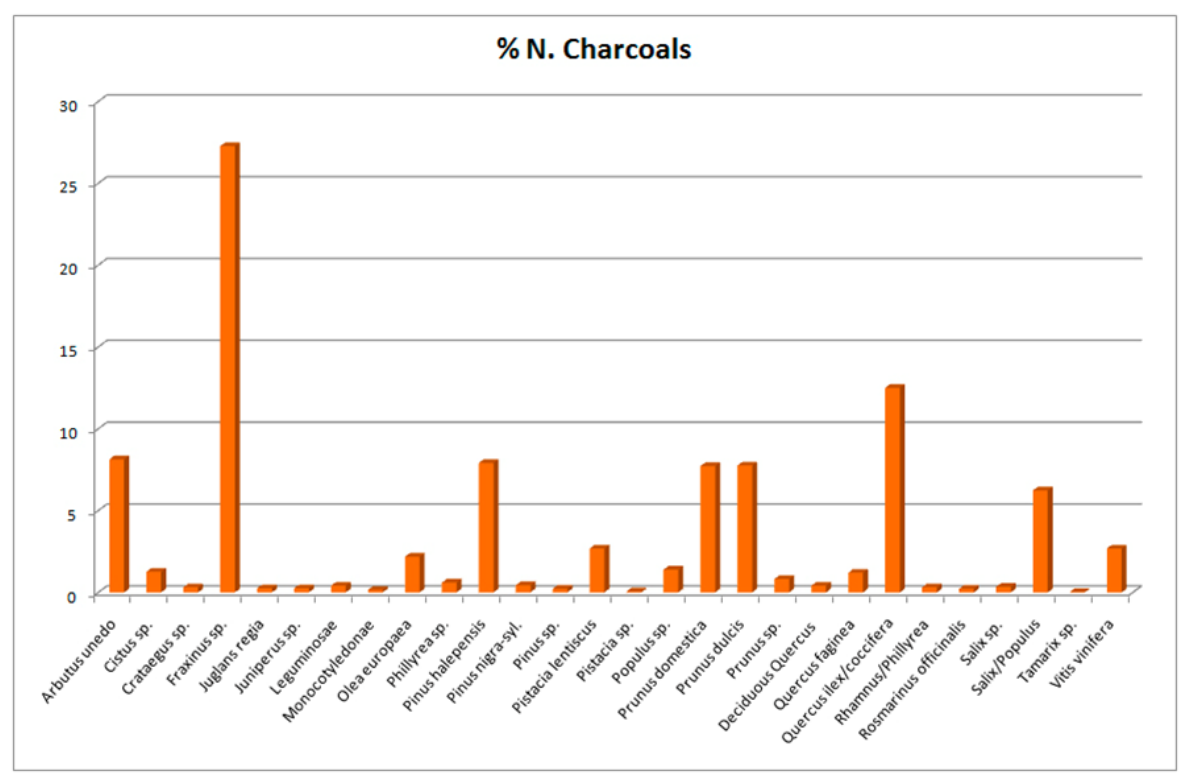

Fig. 4. Relative frequencies of the different taxa in the set of 3,148 charcoal fragments analysed from all areas of the oppidum.

Fig. 4. Frecuencias relativas de los distintos taxones en el conjunto de los 3148 fragmentos de carbón analizados provenientes de todas las áreas del oppidum.

\section{Semi-micro analysis (between areas)}

As indicated above, the areas that were excavated most recently, the Palace and Sanctuary, provided sufficient numbers of charcoal fragments to compare the results. To determine whether the separation of vegetation was the same, we also made a ubiquity analysis for the separation of the taxa in the different spaces or structural complexes defined in them: 20 in the Palace and 28 in the Sanctuary.

The ubiquity results (Fig. 5) indicated that there was a certain disparity between the two areas with respect to the predominant taxa. Thus, in the Palace, the two taxa that appeared in the greatest number of structural complexes were almond and ash, which appeared in 19 of 20 of the complexes, followed by Holm oak/kermes oak, strawberry tree, plum, Aleppo pine, and mastic tree. Meanwhile, in the Sanctuary, the ash appeared in almost all the complexes, i.e. in 25 of 28, followed by Holm oak/kermes oak in 19, willows/poplars, plum, strawberry tree, grapevine,

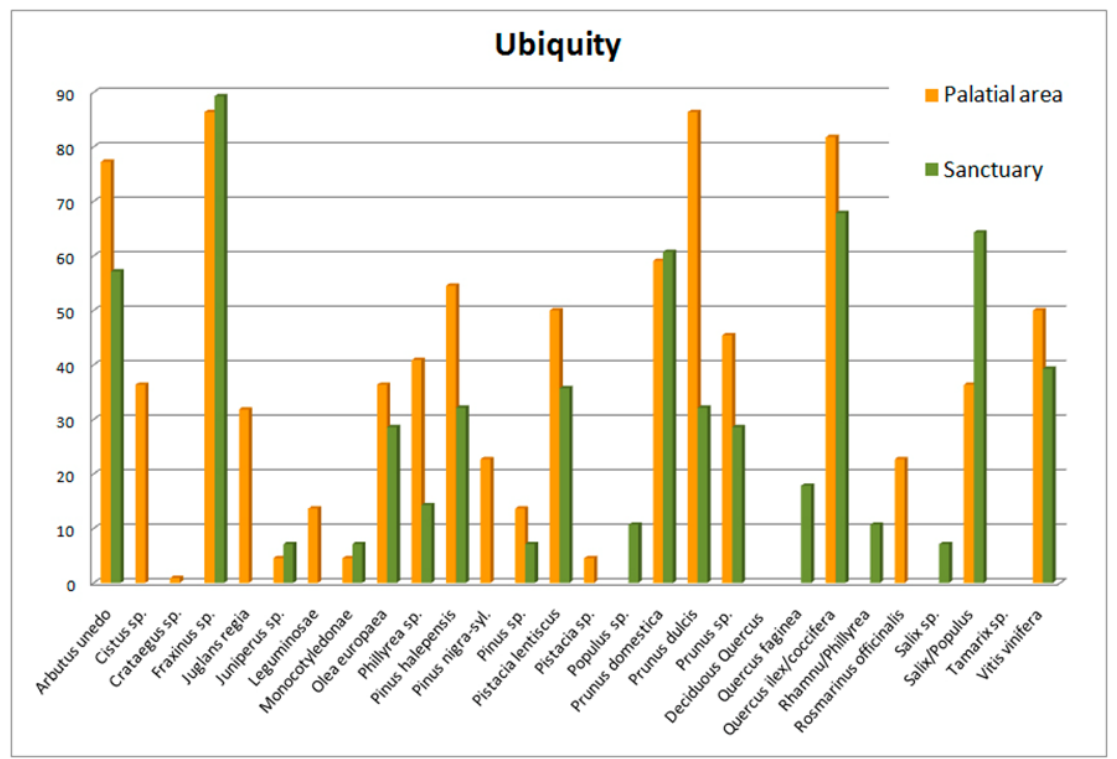

Fig. 5. Comparison of the relative frequencies of the presence of the different taxa between the Palace (22 complexes) and the Sanctuary ( 28 complexes).

Fig. 5. Comparación de las frecuencias relativas de aparición de los distintos taxones entre el Palacio (22 CE) y el Santuario $(28 \mathrm{CE})$ 
and mastic tree between 18 and 10. However, by frequency of appearance in the two different areas, the results were quite uneven (Fig. 6). Meanwhile, in the Sanctuary, with 1,755 fragments analysed, the ashes clearly stood out from the rest of the taxa, with almost $90 \%$ of the charcoal fragments, while the rest of the taxa registered less than $10 \%$. In the Palace, of 1,210 charcoal fragments studied, the 3 main taxa had similar frequency rates, of $16-17 \%$ : Aleppo pine, Holm oak/kermes oak, and almond. The rest of the taxa, except the strawberry tree with $8.5 \%$, registered rates below 5\%. A differential use of vegetation between the two zones can be inferred.
When the taxa were arranged by plant groups and compared between the two areas analysed (Fig. 7), a sharp difference between the four groups appeared in percentage. Whereas the Meso-Supramediterranean vegetation had similar frequencies in the two areas $(2.3$ and $2.1 \%$ ), the riparian vegetation presented greater differences ( 8.25 in the Palace vs. $55.58 \%$ in the Sanctuary), followed by the Thermo-Mesomediterranean vegetation, with 58.45 and $22.79 \%$, respectively. The cultivated trees also differed, although less remarkably ( 24.27 in the Palace vs. $14.4 \%$ in the Sanctuary).

Therefore, there was a certain disparity in the spatial distribution of the taxa, but a great difference

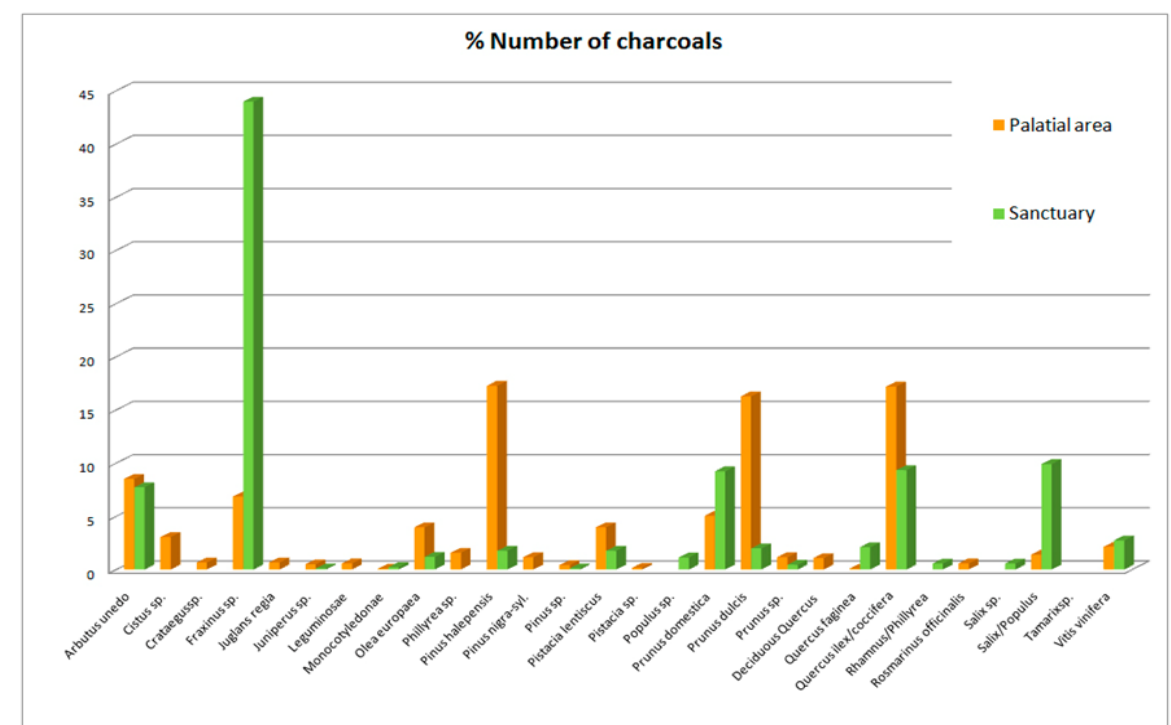

Fig. 6. Comparison of the relative frequency of the different taxa between the Palace $(1,210$ charcoal fragments) and the Sanctuary (1,755 charcoal fragments).

Fig. 6. Comparación de las frecuencias relativas de los distintos taxones entre el Palacio (1210 carbones) y el Santuario (1755 carbones).

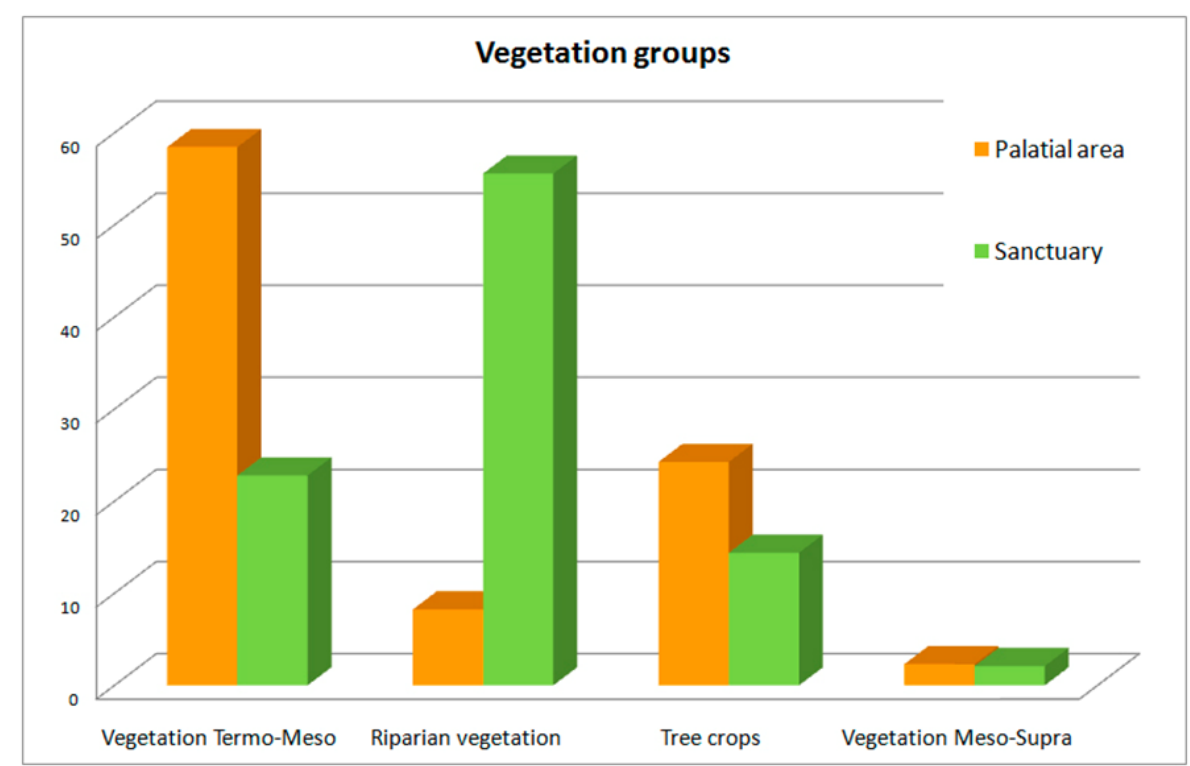

Fig. 7. Comparison of the relative frequency of the vegetation groups between the Palace and the Sanctuary. Fig. 7. Comparación de las frecuencias relativas de los grupos de vegetación entre el Palacio y el Santuario. 
in the frequency or percentages of appearance in each of the two zones. This reflects a different representation of the vegetation. Such differences may reflect either the use of different collection and provisioning areas for woody resources or the differing use of the wood in each area.

Diachronic analysis of the different areas

In view of the differences found between the representation of the different taxa in the Palace and the Sanctuary, we drew the charcoal diagram for each case separately (Figs. 8 and 9) in order to discern whether the vegetation significantly varied over time.

In the Palace, three periods of the Iberian Era were distinguished: Early Iberian (PTIV) from the $6^{\text {th }}$ century B.C., Middle Iberian (PTV, PTVI, and PTVII) from the $5^{\text {th }}$ to the $4^{\text {th }}$ centuries B.C., and the Late Iberian (PTVIII) from the $3^{\text {rd }}$ century B.C..

Chronologically, the results show great uniformity, presenting the same plant composition and similar percentages of representation for each taxon determined, despite the different number of charcoal samples analysed in the three phases determined. The only remarkable difference was the increase in the Holm oak/kermes oak in the $3^{\text {rd }}$ century B.C. and the strong increase of the almond tree in the IV-IV B.C.. Therefore, we can make an overall evaluation for the entire period analysed (Fig. 8).

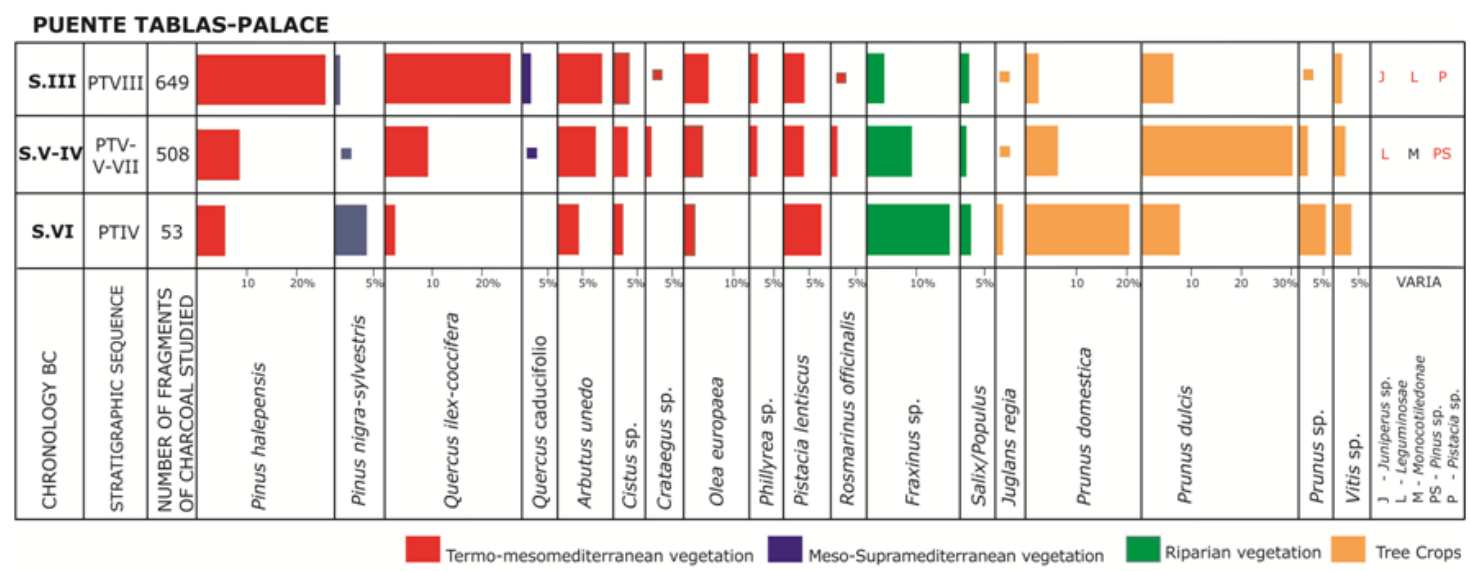

Fig. 8. Charcoal diagram for the Palace of Puente Tablas.

Fig. 8. Diagrama antracológico del Palacio de Puente Tablas.

The image of the vegetation during the $6^{\text {th }}$ to $3^{\text {rd }}$ century B.C. transmitted by the diagram of the Palace of Puente Tablas is of an anthropized landscape, possibly in a mosaic or segmented pattern. In the richest soils, the cultivated areas, and adjacent plains surrounding Puente Tablas, farming involved cereals and legumes identified in the carpological analysis (MONTES 2015), but also cultivated trees such as walnut, plum, and almond, as well grapevine. These woody plants could have grown in independent plots or perhaps along borders or passageways. Meanwhile, the natural vegetation would have developed in the more marginal areas far from the settlement, although several zones can be discerned. One, where the open oak woodland would have developed, as together with the remains of oaks appear shrubby species such as the strawberry tree, mastic tree, wild olive, and phillyrea. The three latter species indicate a warm environment. In the open areas, probably the slopes and rocky soils were covered by Aleppo pines, together with thicket species such as rockrose and rosemary. Along the riverbanks of the Guadalbullón the ash, willow, and poplar would have grown. The small quantity of deciduous oak (possibly Portuguese oak) and black pine is strik- ing. These species grow naturally in mountain areas, or, in the case of the Portuguese oak, in shady, wet refuge areas. Therefore, their appearance implies that these species may have been taken from nearby mountains. This signifies that, around Puente Tablas, a broad area provided wood exploitation for building and fuel.

In the charcoal diagram of the Sanctuary of Puente Tablas (Fig. 9), the stratigraphic phase corresponding to the $6^{\text {th }}$ century B.C., PTIV, could not be represented graphically for having analysed a small quantity of charcoal. For the rest of the phases, however, a considerable number of charcoal samples were analysed, primarily from the $5^{\text {th }}$ century (PTV) and the first half of the $4^{\text {th }}$ century (PTVI), although again the number of charcoal samples analysed diminished in the second half of the $4^{\text {th }}$ century (PTVII). Here, the phase of the $3^{\text {rd }}$ century B.C. did not exist. The plant list for the 3 phases of the High Iberian period was basically the same, except for the absence of the Aleppo pine and almond in the last phase, more for the low amount of charcoal than for ecological reasons. Quantitatively, the percentage of appearance for each taxon also showed concordance between the three phases, more similar between the two phases 
of the $4^{\text {th }}$ century but some difference for the $5^{\text {th }}$ century.

The most outstanding feature was the abundance of riverside species that with $50 \%$ of the representation (Fig. 7) indicate that in this case firewood was collected near the Guadalbullón river (Fig. 2). The presence of ash was also striking, although we could not determine the exact species, followed at some distance by the willows and poplars. The climatic vegetation was less represented, with a notable presence of the remains of Holm oak/kermes oak and strawberry tree as well as the occasional presence of Aleppo pine. The shrubby species such as the wild olive, phillyrea, and mastic tree were sparse and no thicket species appeared. The Portuguese oak appeared occasionally in the phases of the $5^{\text {th }}$ century and first half of the $4^{\text {th }}$ but disappeared in the second half of the $4^{\text {th }}$ century B.C.. Among the cultivated trees, the walnut did not appear and the plum became the most abundant species, while the almond and grapevine appeared consistently although in small quantities.

\section{PUENTE TABLAS-SANCTUARY}

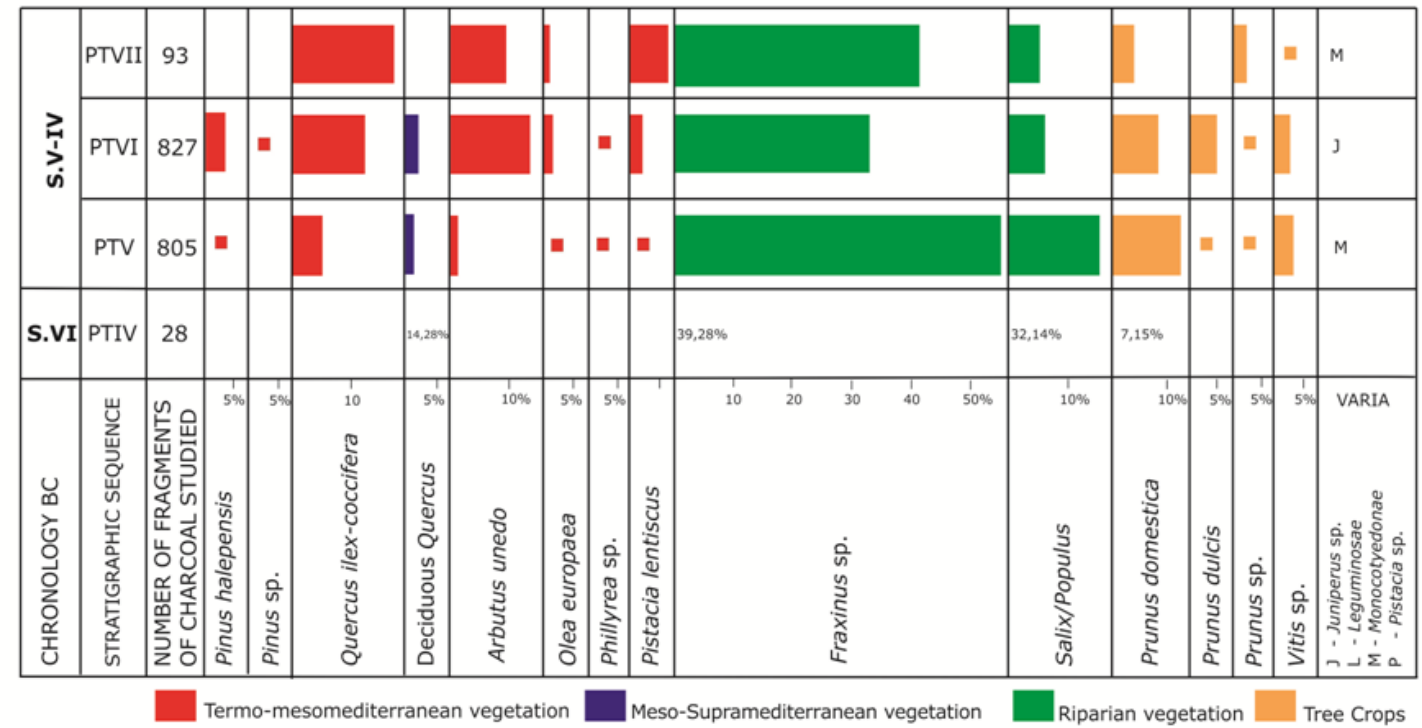

Fig. 9. Charcoal diagram of the Sanctuary of Puente Tablas. Fig. 9. Diagrama antracológico del Santuario de Puente Tablas.

\section{Micro analysis (between structures)}

The excavation of numerous rooms and structural complexes both in the Palace as well as in the Sanctuary and the definition in many cases of its functionality led us to look for significant differences in the results of the charcoal analyses.

In the Sanctuary, we firstly evaluated the taxonomic composition of each of the 15 structural complexes in which charcoal fragments were recovered and analysed. Of these 15 complexes, 4 did not belong strictly to the Sanctuary (AE, S6, AE-Ext. and Cubeta) but to its service area (RUIZ et al. 2015), and thus they were included in the analysis. Figure 10 shows that in none of the complexes did all 12 taxa appear. In spaces J and U, 11 were found while the same number appeared in AE.Ext., Y-Int. and Cubeta. In the rest of the structural complexes the taxonomic composition varied between 1 and 8 .

On the other hand, the analysis of the spatial distribution of each of the 12 main taxa (of 18 identified) in the 15 structural complexes with sufficient charcoal of the 28 excavated (Fig. 10) highlighted the ashes that appeared in 14 cases, followed by the strawberry tree in 12 , and willows/poplars in 11 . In 10 complexes appeared Holm oak/kermes oak, mastic tree, and plum. Therefore, the riverside species appeared in most of the spaces and those that were assumed to be most used, followed by those of the climatic vegetation and the crops in last place.

In addition, to evaluate the use of each species in these contexts, we compared the relative frequencies of the same 12 most abundant taxa among the 5 structural complexes with sufficient charcoal fragments (between 166 and 317; Fig. 11). The circular diagrams of these frequency values show a similar composition in 4 cases, with ashes being most abundant $(44-71 \%)$, followed by a similar percentage of willows/poplars $(8-24 \%)$ and plum $(7-21 \%)$. However, in space $\mathrm{J}$, the main taxon was the Holm oak/ kermes oak at $27 \%$, followed by ashes at $25.9 \%$, and then the rest of the taxa at less than $10 \%$.

The singularity of this space is clearly reflected in Figure 12, where the taxa are categorized according to the vegetation group to which they belong. The climatic vegetation predominates with more than $50 \%$ of the representation. In the other structural spaces, however, the riparian species are 
most represented, ranging between 56 and $79 \%$, while the climatic vegetation falls to between 5 and $26 \%$. The cultivated trees maintain similar frequencies in all 5 complexes $(10-24 \%)$.
Therefore, as in the previous cases, space $\mathrm{J}$ can be clearly distinguished, for the number of taxa present, but mainly for the percentage distribution of the species present and the majority representa-

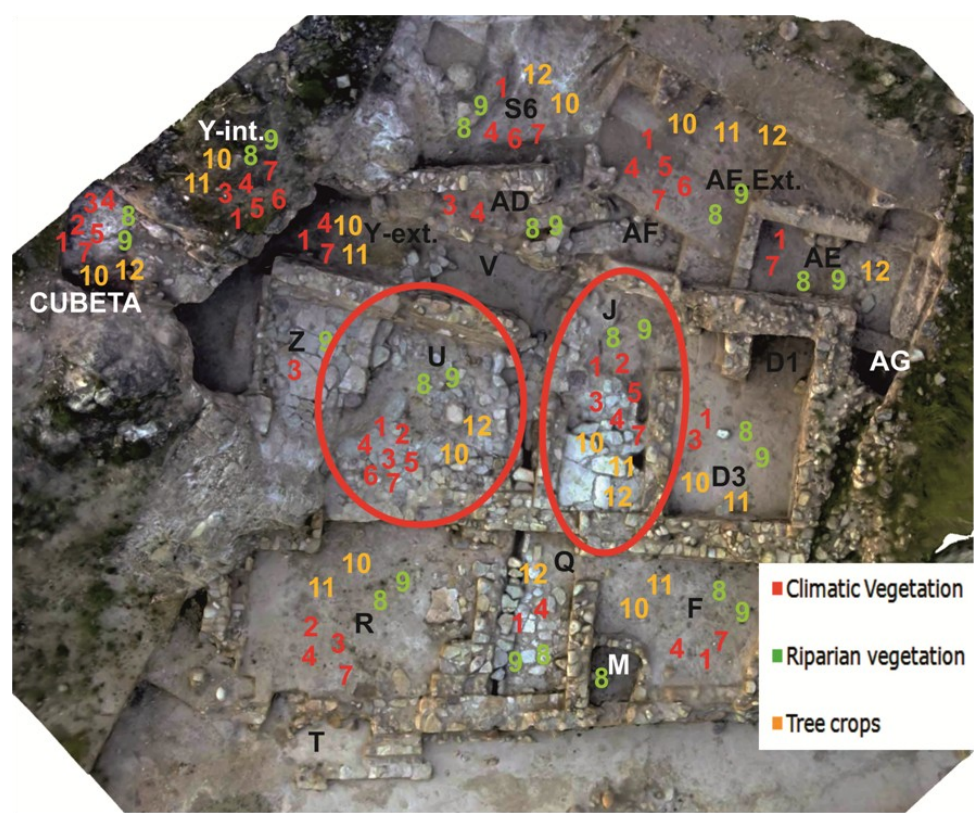

Fig. 10. Ubiquity of the taxa in the different structural complexes of the Sanctuary of Puente Tablas: 1. Quercus ilex/coccifera, 2. Quercus faginea, 3. Pinus halepensis, 4. Arbutus unedo, 5. Olea europaea, 6. Rhamnus/Phillyrea, 7. Pistacia lentiscus, 8 Fraxinus sp., 9. Salix/Populus, 10. Prunus domestica, 11. Prunus dulcis, 12. Vitis $\mathrm{sp}$. Fig. 10. Ubicuidad de los taxones en los distintos Complejos Estructurales del Santuario de Puente Tablas: 1. Quercus ilex/coccifera, 2. Quercus faginea, 3. Pinus halepensis, 4. Arbutus unedo, 5. Olea europea, 6. Rhamnus/Phillyrea, 7. Pistacia lentiscus, 8. Fraxinus sp., 9. Salix/Populus, 10. Prunus domestica, 11. Prunus dulcis, 12. Vitis sp.

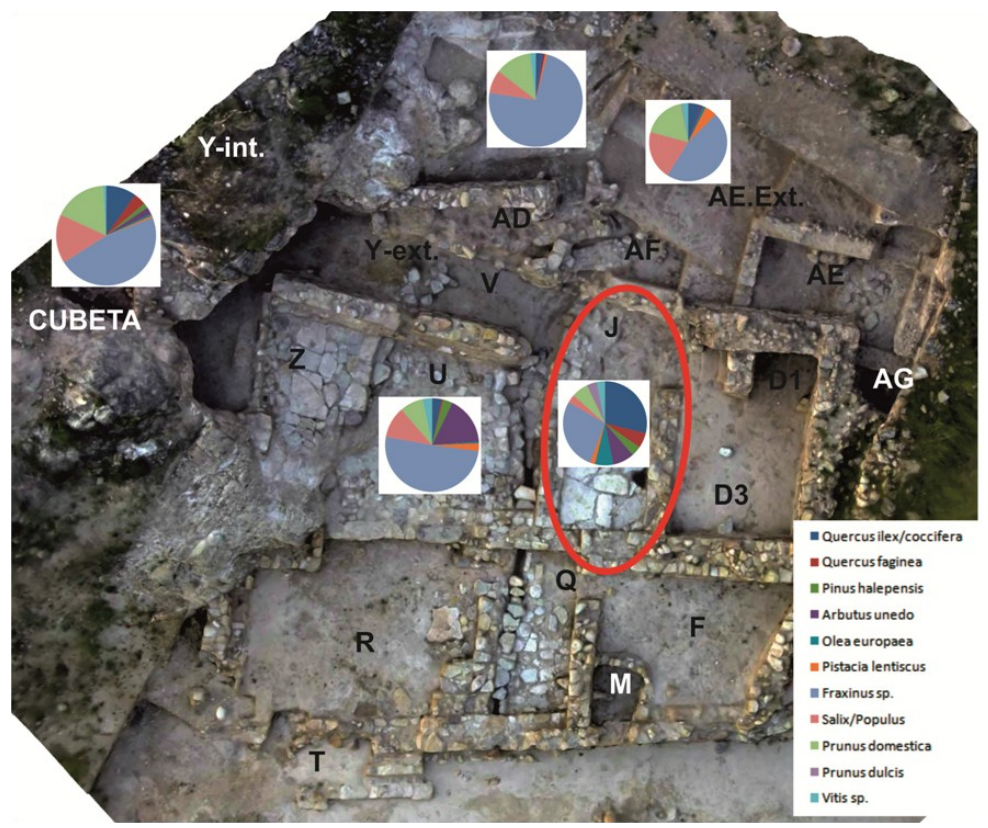

Fig. 11. Graphic representation of the relative frequencies of the 12 main taxa in the Sanctuary of Puente Tablas.

Fig. 11. Representación gráfica de las frecuencias relativas de los 12 taxones mayores en los Espacios del Santuario de Puente Tablas. 
tion of the climatic vegetation as opposed to the riparian vegetation of the rest of the structural complexes. This space was defined by its excavation as a place for animal sacrifice, as numerous remains of fauna were found (RUIZ et al. 2015). Therefore, we infer that the charcoal from firewood was used in cooking and preparation, for which nearby natural climax vegetation was used, this fuel having a medium-high calorific value (Elvira \& HeRnANDo 1989). However, space U, defined as an open space with an altar, as in the other 3 structural complexes, defined as service areas of the Sanctuary, used species collected along the Guadalbullón river, especially ashes.

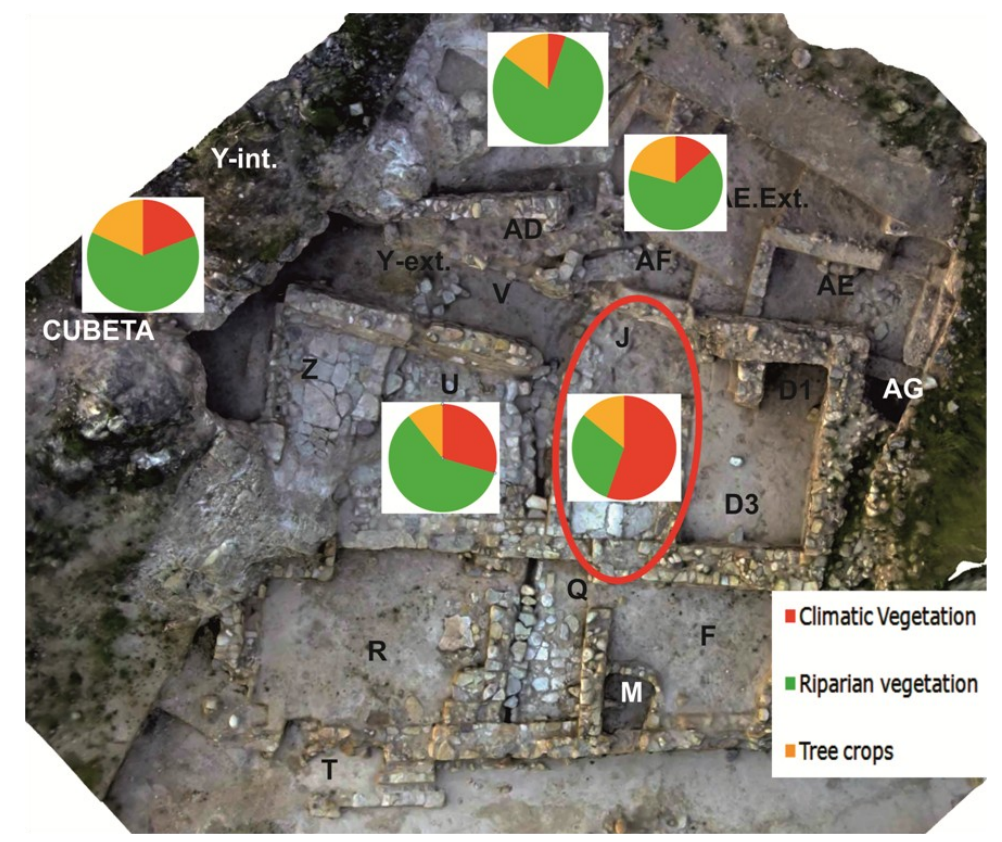

Fig. 12. Graphic representation of the relative frequencies of the vegetation groups in the Sanctuary of Puente Tablas.

Fig. 12. Representación gráfica de las frecuencias relativas de los Grupos de Vegetación en los Espacios del Santuario de Puente Tablas.

In the village, of the 22 structural complexes defined, only 5 presented a high enough number of charcoal samples to be able to compare them, between 65 and 315 fragments, the rest rendering 8 to 43 fragments. Therefore, a comparison was made only of the absolute frequencies of the taxa determined in these spaces (Fig. 13). Three of these spaces $(h, p, r)$ presented a similar composition, with the Aleppo pine as the most represented species, followed by wild olive and Holm oak/kermes oak. Spaces $r$ and $p$ belonged to the productive area of the Palace, the former being a flower mill, which implies the use of hardwoods with a medium -high calorific value. Space $h$ was defined as a semi -open area with a bath. The fact of having a taxonomic composition similar to that of the previous areas could indicate that there may have been a hearth where water was heated. However, the majority presence of Aleppo pine at the levels of collapse would be related to its use in the construction.

In space $\mathrm{n}$, defined as a storage area and for pressing grapes or olives, the Holm oak/kermes oak constituted the predominant taxon, followed by strawberry tree. This space in the street and on the outside of the Palace received the refuse from the domestic fires and from nearby buildings, and therefore all the forest and thicket species appear, but plum stands out, though this may be circumstantial.

\section{EVALUATION AND DISCUSSION}

The overall charcoal data of Puente Tablas indicate great agricultural development of the society, since long-term crops such as fruit trees require ample agricultural knowledge. In addition, this reflects high social development to guarantee ownership of these crops that take years to bear fruit. The field crops were cereals and legumes (MONTES 2015) and the tree crops were mainly fruit and nut trees such as the plum, walnut, and almond, in addition to grapevine. These species would be used on the one hand for local consumption, but also for trade, especially in the case of grapes, which would be used to produce wine.

In the cases of olive and grape, which can represent both wild as well as cultivated varieties, are different. Firstly, the charcoal identified probably belonged to the wild olive variety of the area, since, in Andalusia, the olive did not expand until the Roman period (RODRÍGUEZ-ARIZA \& MONTES 2004). In the case of Puente Tablas, which, as 


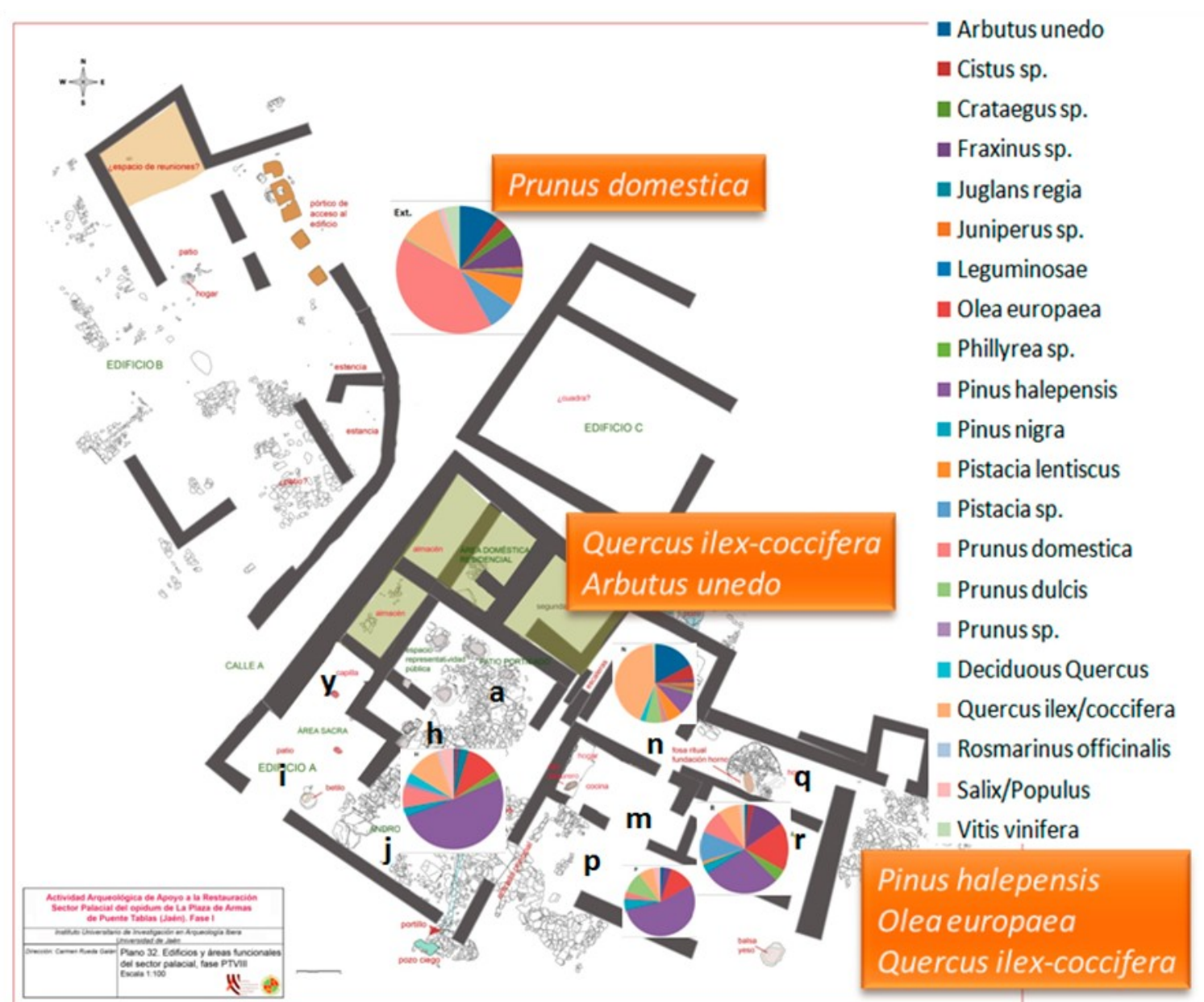

Fig. 13. Graphic representation of the relative frequencies of the taxa in the spaces of the Palace of Puente Tablas. Fig. 13. Representación gráfica de las frecuencias relativas de los taxones en los Espacios del Palacio de Puente Tablas.

commented above, lies in a contact area between Thermo- and Mesomediterranean vegetation, the wild olive appears naturally, registering moderate percentages in previous periods (RODRÍGUEZARIZA 2011). Meanwhile, grape was almost surely cultivated, as from the $7^{\text {th }}$ century B.C., it appears systematically in all studies of the area (RODRÍGUEZ-ARIZA 2014), and its seeds are found in great quantities at the site itself (MONTES 2015).

This process of the advancement in tree growing and more intensive agriculture provoked changes in the surroundings of the settlements (RoDRíGUEZ-ARIZA 2012), in this case Puente Tablas. The charcoal analysis points to a marked degradation of the vegetation, although areas or patches with natural vegetation remained where a degraded oak woodland developed, while in the Guadalbullón valley a rather large amount of riparian vegetation persisted although most of the plain was occupied by farmland. On the other hand, there was a number of taxa that, although they appear in small quantities (Portuguese oak-Pyrenean oak and black pine/Scots pine) imply an area for firewood collection larger than in the immediate surroundings of the village.
The bioclimatic parameters under which these species developed situate them in the nearby mountains of the Subbetic Systems to the south of the settlement at a minimum distance of $10 \mathrm{~km}$.

The charcoal results, with the plant groups recorded (Figs. 8, 9, and 12), support the division of 4 source areas for wood used for building and burning at Puente Tablas: the first was in the surroundings of the Guadalbullón river, the second in the surroundings of the village, the third in the crop fields (Fig. 2), and the fourth in nearby mountains. Therefore, the exploitation of each of these areas would depend on the villagers' needs and function of the wood used.

The function of the charcoal analysed is difficult to determine with precision when fragments appear in a dispersed manner throughout the sediment excavated. However, some annotations are due with respect to the results presented above.

It might be thought that in the Palace these charcoal fragments came mainly from the firewood used as fuel in the domestic hearths. There, most species of the forest and thicket areas were used, complemented by certain riparian species, although 
these are not the best to burn, and by the remains of pruning debris from cultivated trees. Aleppo pine, appears mainly in the rubble of the collapsed levels, implying that it was used as a construction material, although this is not certain as it was not detected in the levels of fire.

The vegetation determined in the Sanctuary, except for space J, where vegetation typical of domestic fires is most frequent, is characterized by a predominance of ash. This high frequency of ash in the area of the Sanctuary poses intriguing questions with respect to it uses or function: Was this wood burned in rituals? Was it used in the construction of the Sanctuary? Did it have special symbolism? These questions remain difficult to answer from the charcoal record recovered. It does, however, indicate a differentiated use for woody species in the surroundings in comparison with that documented in the Palace.

The references on the symbolism of ash come above all from the Germanic world, where it was a sacred tree called Ygdrasill. In the Mediterranean world, the ash "was one of the seasonal trees of a goddess important for her pastoral followers for her association with storms and the month in which lambs are born, a third of the sacred year" (RIVERA \& OBÓN 1991: 905). According to Robert Graves $(1983: 218-220)$ the ash in Greece was sacred to Poseidon, and therefore to the power of the sea, or to the power that resides in water. It is related to the third month, which is the one of floods and extends from 18 February to 17 March. These dates coincide roughly with the days when the sun illuminates the chapel of the goddess in the complex of the Eastern Gate (or Sun Gate), 20 February and the spring equinox 21 March (RUIZ et al. 2015: Fig. 2).

In addition, the symbolism of the ash in relation to the goddess and her appearance in the Sanctuary may be related to the sacred fires there and where sulphur was used for purification, as narrated in different passages of the Iliad and Odyssey of Homer $(2001,2007)$. The chemical analysis of numerous ceramic vessels have evidenced the existence of sulphur in their walls (PARRAS et al. 2015). As narrated in the Odyssey (22:480-484), sulphur was used for purifying fires. It is plausible that such fires were made primarily from ash branches, as appears to be the case for the composition and representation in the space $U$, an open area where there was an altar and where more vessels with sulphur have been found. Therefore, the appearance of ash in the Sanctuary is related to its participation in these ritual fires.

\section{REFERENCES}

BADAL, E.; Bernabeu, J. \& Vernet, J.L. 1994. Vegetation changes and human action from the Neolithic to the Bronze Age (7000e4000 BP) in Alicante, Spain, based on charcoal analysis. Vegetation History and Archaeobotany 3: 155-166.
ChaBAL, L. 1992. La représentativité paléoecologique des charbons de bois archéologiques issus du bois de feu. Bulletin de la Societe Botanique de FranceLettres Botaniques 139, 213-236.

ElVIRA, L.M. \& HeRnANDO, C. 1989. Inflamabilidad y energía de las especies de sotobosque (Estudio piloto con aplicación a los incendios forestales). INIA, Madrid.

FIGUEIRAL, I. 1993. Charcoal analysis and the vegetational evolution of North-West Portugal. Oxford Journal of Archaeology 12, 209-222.

FIgUEIRAL, I. 1996. Wood resources in north-west Portugal: their availability and use from the late Bronze Age to the Roman period. Vegetation History and Archaeobotany 5: 121-129.

García, M.S. \& GraU, E. 2005. Aprovechamiento de los recursos leñosos en la fase protohistórica de Punta de los Gavilanes (Mazarrón, Murcia). In Anales de Prehistoria y Arqueología, 21: 51-68.

Graves, R. 1983. La Diosa blanca. Alianza Editorial. T. I y II. Madrid.

Homero, 2001. La Iliada. Translated by Emilio Crespo. Editorial Gredos, Madrid.

Homero, 2007. La Odisea. Translated by Mariano Benavente. Ediciones Clásicas, Madrid.

JACQUIOT, C. 1955. Atlas d'anatomie des bois des coniféres. Editions du Centre technique du Bois, Paris.

JACQUiOT, C.; TREnARD, Y. \& Dirol, D. 1973. Atlas d'anatomie des bois des angiospermes. Editions du Centre technique du Bois, Paris.

MARSTON, J.M. 2009. Modeling wood acquisition strategies from archaeological charcoal remains. Journal of Archaeological Science 36: 2192-2200.

MonTES, E., 2015. La agricultura y la gestión de los recursos vegetales en el Oppidum de Puente Tablas. In: A. RUIZ \& M. Molinos (Eds.), Jaén tierra Ibera. 40 años de investigación y transferencia. Universidad de Jaén, Jaén, pp. 127-136.

PARras, D.J.; SÁNChez, A., Tuñón, J.A., RuedA, C., RAMOS, N. \& GARCÍA-REYES, J.F. (2015). Sulphur, fats and beeswax in the Iberian rites of the sanctuary of the oppidum of Puente Tablas (Jaén, Spain). Journal of Archaeological Science: Reports, Volume 4: 510-524.

RiverA, D. \& OBÓN, C. 1991. La guía de Incafo de las plantas útiles y venenosas de la Península Ibérica y Baleares (excluidas medicinales). Incafo, Madrid.

RodrigueZ-ArizA, M.O. \& Esquivel, J.A. (1989-90). Una aplicación del análisis de correspondencias en el antracoanálisis de Los Millares. Cuadernos de Prehistoria de la Universidad de Granada, 14-15: 81-109.

RoDRÍGUEZ-ARIZA, M.O. 2011. Evolución y uso de la vegetación durante la Prehistoria en el Alto Guadalquivir. Menga 02: 34-57.

RODRÍGUEZ-ARIZA, M.O. 2014. Intensificación agraria, arboricultura y vegetación durante el I milenio a.n.e. en Andalucía a partir de la Antracología. Cuadernos de Prehistoria y Arqueología 22 (2012): 333-358.

RodríGueZ-ArizA, M.O. \& MONTES, E. 2005. On the origin and domestication of Olea europaea L. (olive) in Andalucía, Spain, based on the biogeographical 
distribution of its finds. In R. BUXÓ, S. JACOMET \& F. BITMANN (Eds.), Interaction between man and plants. New Progress in Archaeobotanical Research. Vegetation, History and Archaeobotany 14 551-561.

RodrígueZ-ArizA, M.O. \& Montes, E. 2010. Paisaje y gestión de los recursos vegetales en el yacimiento romano de Gabia (Granada) a través de la arqueobotánica. Archivo Español de Arqueología 86: 85107.

RodrígueZ-ArizA, M.O. \& PradAs, C. 2015. El paisaje de Puente Tablas a partir de la Antracología. In A RUIZ \& M. Molinos (Eds.), Jaén tierra Ibera. 40 años de investigación y transferencia. Universidad de Jaén, Jaén, pp. 119-126.

Rubiales, J.M.; Hernández, L., Romero, F. \& SAnZ, C. 2011. The use of forest of resources in central Iberia during the Late Iron Age. Insights from the wood charcoal analysis of Pintia, a Vaccaean oppidum. Journal of Archaeological Science 38: 1-10.

Ruiz, A. \& Molinos, M., 1998. The Archaeology of the Iberians. Cambridge University Press, Cambridge.

RuIZ, A. \& Molinos, M., 2008. Iberos en Jaén. Universidad de Jaén, Jaén.

Ruiz, A. \& Molinos, M. 2015. Jaén, tierra ibera. 40 años de investigación y transferencia. Jaén, Universidad de Jaén.

RuIZ, A. \& Molinos, M. 2015. La fortificación del oppidum de la Plaza de Armas de Puente Tablas. In A. RuIz \& M. Molinos (Ed.), Jaén, tierra ibera. 40 años de investigación y transferencia. Jaén, Universidad de Jaén: 45-53.
Ruiz, A.; Molinos, M., Fernández, R., PéRez, M. \& Rue DA, C. 2015. El Santuario de la Puerta del Sol. In A Ruiz \& M. Molinos (Ed.), Jaén, tierra ibera. 40 años de investigación y transferencia. Jaén, Universidad de Jaén: 93-106.

Ruiz, A.; Molinos, M., Rueda, C. \& Fernández, R. 2015 El palacio y el urbanismo del oppidum de Puente Tablas. In A. RuIz \& M. Molinos (Ed.), Jaén tierra ibera. 40 años de investigación y transferencia. Jaén, Universidad de Jaén: 107-118.

SÁnchez, A.; Parras, D.J., TuÑón, J.A., Rísquez, C., Rodríguez, M.O., Montejo, M., RAMOS, N., García, J.F. \& MÁrquez LóPez, F., 2014. Physical-chemical analysis for the research and the valorisation of the oppidum of Puente Tablas (Jaén, Spain). In: M.A. Rogerio-CANDElerA, (Ed.) Science, Technology and Cultural Heritage. Taylor \& Francis Group, London, pp. 103-108.

SCHWEINGRUBER, F. 1990. Anatomie europäischer Hölzer. Bern and Stuttgart.

SCHWEINGRUBER, F.H.; BöRnER, A. \& SCHUlze, E.D. 2011 Atlas of Stem Anatomy in Herbs, Shrubs. Volume 1. Springer.

SCHWEIngRuBER, F.H.; BÖRnER, A. \& SCHUlze, E.D. 2013 Atlas of Stem Anatomy in Herbs, Shrubs. Volume 2. Springer.

VERNET, J.L. 1997. L'homme et la forêt méditerranéenne: de la préhistoire à nos jours. Errance, Paris.

VERnET, J.L. (Coord.) 2001. Guide d'identification des charbons de bois préhistoriques et récents. CNRS Editions, Paris. 